\title{
The structure and dynamics of phytoplankton assemblages from the inner part of the Thermaikos Gulf, Greece. I. Phytoplankton composition and biomass from May 1988 to April 1989
}

\author{
Georgios Nikolaides \& Maria Moustaka-Gouni \\ Department of Botany, School of Biology, University of Thessaloniki; \\ GR-54006 Thessaloniki, Greece
}

\begin{abstract}
Qualitative and quantitative analyses of phytoplankton from the inner part of Thermaikos Gulf were carried out in the period May 1988-April 1989. A total of 154 taxa were identified in the phytoplankton. the monthly values of the phytoplankton biomass ranged between 614 and $6700 \mathrm{mg} / \mathrm{m}^{3}$ (wet weight). The seasonal development of the phytoplankton biomass exhibited three peaks. Diatoms, dinoflagellates and cryptophytes were the most important constituents of the gulf phytoplankton. Throughout the year, five different phytoplankton assemblages were distinguished.
\end{abstract}

\section{INTRODUCTION}

The Gulf of Thermaikos is of both biological and socio-economical interest. Some decades ago, it was regarded as one of the richest areas in the production of fish and molluscs. During the sixties, however, a gradual decrease in the fish production and in species diversity was detectable. Less fish were produced as the domestic and industrial development of the city situated on the shores of the Gulf of Thessaloniki became more evident. In the period 1960-1990, its human population augmented from 300000 to 1000000 people. It should be mentioned here that the whole volume of the domestic and part of the industrial wastes are discharged without any previous treatment along the northwestern coasts of the Gulf, that is into its inner part.

The first information regarding the effects of the city water sewage on the benthic vegetation of the Gulf is given by Anagnostidis (1968) and is later confirmed by Haritonidis (1978) and Nikolaidis (1985). Similar evidence is rendered by the study on the zoobenthos in the research area (Koukouras, 1979; Zarkanellas, 1980). As concerns the phytoplankton of Thermaikos Gulf, the papers by Athanasopoulos (1931a, b), Anagnostidis (1968), and Friligos \& Kousouris (1984) did not provide ample information on the structure and dynamics of the phytoplankton assemblages.

The study of the Gulf phytoplankton was initiated in May 1988 within the frame of an interdisciplinary research project investigating the oceanographic elements of the Gulf. The present paper is the first account on the phytoplankton composition and biomass in Thermaikos Gulf. 


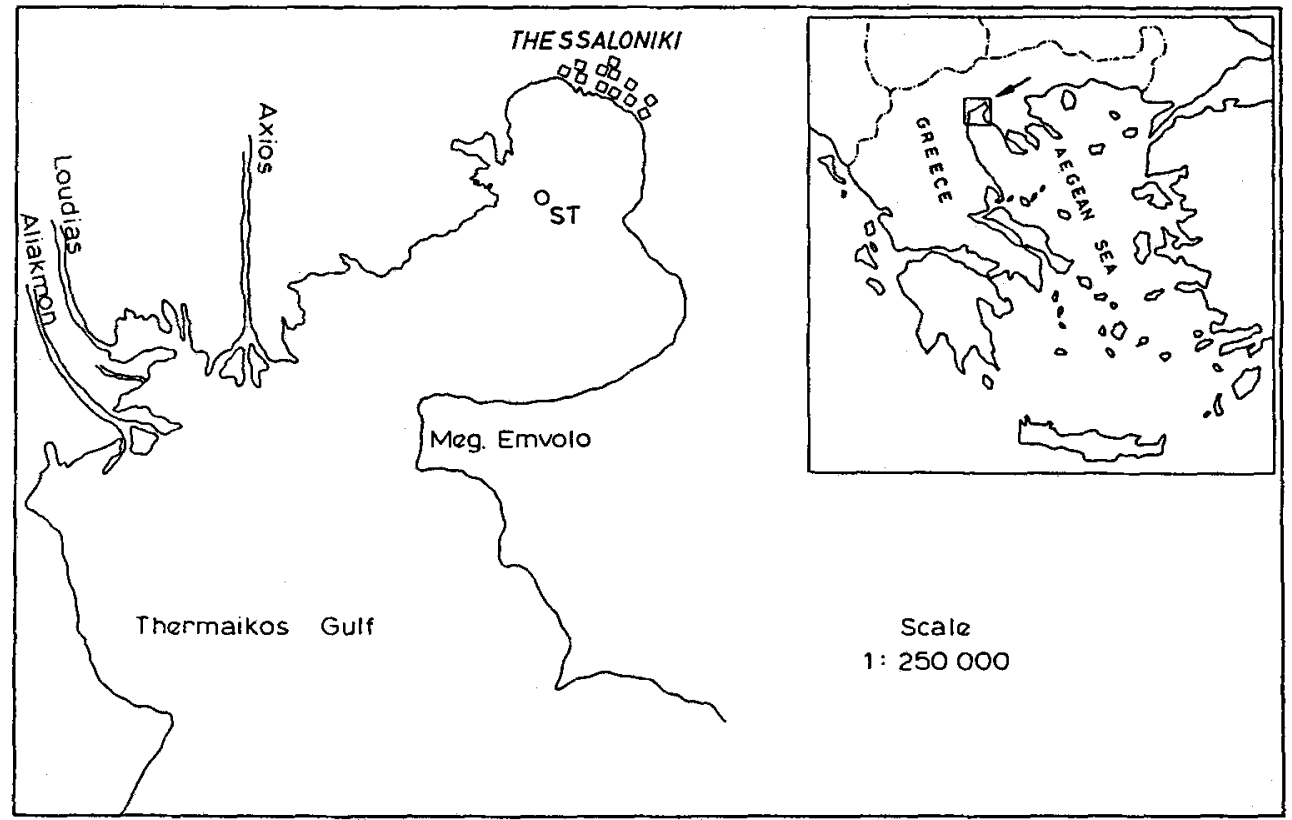

Fig. 1. The study area

THE STUDY AREA

The Thermaikos Gulf (Fig. 1) is situated in the northwest of the Aegean Sea (Eastern Mediterranean). The city of Thessaloniki with its intensive industrial activity ( 1000000 inhabitants) is spread along the northeastern coasts of the gulf. Three of the largest rivers in N. Greece, which cover an extensive drainage area of the Balkan southwestern peninsula, discharge their domestic sewage into the gulf. Apart from the waters of the rivers Axios, Loudias and Aliakmonas (annual mean water flow $150 \mathrm{~m}^{3} / \mathrm{sec}$ ), the Thermaikos Gulf is the daily recipient of approximately $200000 \mathrm{~m}^{3}$ raw domestic and industrial wastes of the city of Thessaloniki.

\section{METHODS}

Sampling was carried out at monthly intervals from May 1988 to April 1989, at one station (ST., Fig. 1). The sampling station, in a central position in the Gulf, is three miles away from the sites where sewage and industrial wastes are discharged. The samples were taken using a Friedinger water sampler at three depths in the euphotic zone.

Water temperature and salinity were measured using a portable WTW temperaturesalinity-meter. A white Secchi disk $20 \mathrm{~cm}$ in diameter was used to measure water transparency. Chemical analyses of water were made using the methods of Strickland \& Parsons (1968) or, for ammonia, the method of Liddicoat et al. (1976).

Determination of algal species was made using the determination keys and mono- 


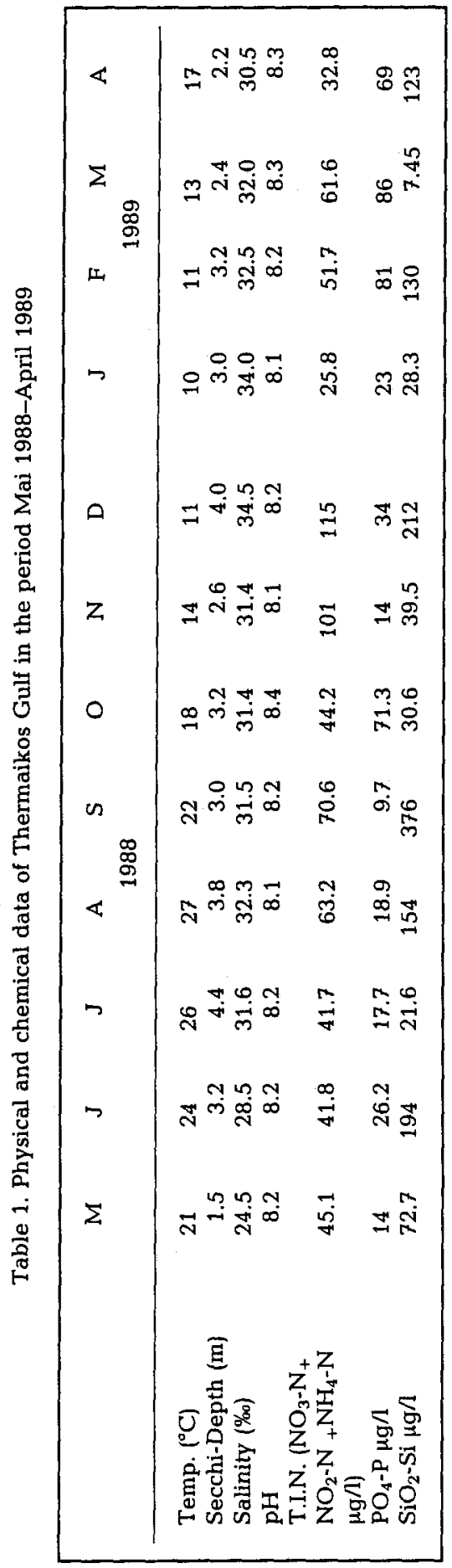


graphs of Hustedt (1930), Schiller (1933, 1937), Cupp (1943), Campbell (1973), Drebes (1974) and Rampi \& Bernhard (1980).

The algae were counted with an inverted microscope using Utermöhl's (1958) sedimentation method. A special computer program was adapted for counting. The determination of the phytoplankton biomass (wet weight) was based on the calculation of the volume of each species from appropriate geometric formulae (Edler, 1979). The volume of algae was transformed into biomass (wet weight), assuming that the specific gravity of the algae is 1 (one). In the present study, at least 25 individuals were measured for each important species in each sample and no standard cell volumes were used. The program Excel with a Macintosh II computer was used for this calculation.

\section{RESULTS}

\section{Environmental conditions}

Some physico-chemical features of Thermaikos Gulf are provided in Table 1. A more detailed report of the changes of the nutrients in this area are presented by Nikolaides \& Moustaka-Gouni (in prep.).

The minimum of water temperature $\left(10^{\circ} \mathrm{C}\right)$ throughout the year was observed in January and the maximum $\left(27^{\circ} \mathrm{C}\right)$ in August. The water column was stratified in the summer while water mixing began in October. Salinity changed significantly ranging between $24.5 \%$ (May) and $34.5 \%$ (December). Water transparency (Secchi depth) ranged from 1.5 to $5.6 \mathrm{~m}$ with the lowest values in springtime $(1.5-2.4 \mathrm{~m})$.

Concentrations of phosphate-phosphorus were high in late winter and early in spring ( $\max .86 \mu \mathrm{g} \mathrm{PO}_{4}-\mathrm{P} / \mathrm{l}$ ), whereas the lowest values (min. $9.7 \mu \mathrm{g} \mathrm{PO}_{4}-\mathrm{P} / \mathrm{l}$ ) were measured during the warm period (May-September). Thetotal inorganic nitrogen (TIN) and silicon were observed to be at low levels throughout the year, the former reaching a maximum $(115 \mu \mathrm{g}$ TIN $/$ ) in December. The concentrations of silicon were variable fluctuating between $8 \mu \mathrm{g} \mathrm{SiO}_{2}-\mathrm{Si} / 1$ in March and $376 \mu \mathrm{g} \mathrm{SiO}{ }_{2}-\mathrm{Si} / 1$ in September.

\section{Phytoplankton composition}

A total of 154 phytoplankton taxa was identified during the period May 1988 to April 1989. The list of species is given in Table 2, including species from quantitative samples only. The Dinophyceae comprise the highest number of species (84) followed by Bacillariophyceae (51), Cryptophyceae (5), Prymnesiophyceae (6), Prasinophyceae (4), Euglenophyceae (2), Chrysophyceae (Dictyochalis) (1) and Chlorophyceae (1). The number of taxa belonging to the Prymnesiophyceae, Cryptophyceae, Prasinophyceae, Chrysophyceae and Chlorophyceae should be larger than the one mentioned before since many taxa of these classes, their identification being difficult, have been included in the category of the $\mu$-flagellates.

The species which are abundant and important contributors to the phytoplankton biomass belong to the Bacillariophyceae (Cerataulina bergonii, Chaetoceros socialis, Coscinodiscus granii, Ditylum brightwellii, Leptocylindrus danicus, L. minimus, Nitzschia closterium, N. "seriata", Rhizosolenia delicatula, $R$. fragilissima, $R$. setigera, Schroederella schroederi, Skeletonema costatum, Thalassionema nitzschioides, Thalas- 
Table 2. List of species

Bacillariophyceae

Bacteriastrum hyalinum Lauder

Bellerochea jucatanensis v. Stosch

Cerataulina bergonii Peragallo

Chaetoceros affinis Lauder

C. compressus Lauder

C. costatus Pavillard

C. crinitus Schütt

C. curvisetus Cleve

C. danicus Cleve

C. decipiens Cleve

C. densus Cleve

C. diversus Cleve

C. gracilis Schütt

C. laciniosus Schütt

C. lauderi Ralfs

C. lorenzianus Grunow

C. peruvianus Brightwell

C. protuberans Lauder

C. socialis Lauder

Coscinodiscus granii Gough

Coscinodiscus sp.

Dactyliosolen mediterraneus Peragallo

Detonula confervacea (Cleve) Gran

Ditylum brightwellii (West) Grunow

Eucampia zoodiacus Ehrenberg

Guinardia flaccida (Castr.) Peragallo

Hemiaulus hauckii Grunow

Leptocylindrus danicus Cleve

L. minimus Gran

Melosira sp.

Nitzschia closterium (Ehrenb.) W. Smith

N. seriata Cleve

Odontella mobiliensis (Bail.) Grunow

Rhizosolenia alata Brightwell

$R$. calcar-avis M. Schultze

$R$. delicatula Cleve

$R$. fragilissima Bergon

$R$. robusta Norman

$R$. setigera Brightwell

$R$. shrubsolei Cleve

R. stolterfothii Peragallo

Schroederella schroederi (Bergon) Pavillard

Skeletonema costatum (Grev) Cleve

Thalassionema nitzchioides Grunow

Thalassiosira anguste-lineata (A. Schmidt) Fryxell et Hasle

$T$. eccentrica (Ehrenb.) Cleve

T. minima Gaarder

$T$. polychorda (Gran) Pr.-Lavrenko

$T$. rotula Meunier

Thalassiosira sp.

Thalassiothrix frauenfeldii Grunow

Thalassiothrix mediterranea Pavillard 
Table 2 (Continued)

\section{Dinophyceae}

Amphidinium sp.

Blepharocysta splendor maris Schütt

Cachonina niei Loeblich III

Ceratium candelabrum (Ehrenb.) Stein

C. concilians Jörgensen

C. declinatum Karsten

C. furca var. eugrammum (Ehrenb.) Jörgensen

C. furca (Ehrenb.) Claparede \& Lachmann

C. fusus (Ehrenb.) Dujardin

C. hexacanthum Gourret

C. lineatum (Ehrenb.) Cleve

C. macroceros (Ehrenb.) Cleve

C. minutum Jörgensen

C. pulchellum Schröder

C. symmetricum Pavillard

C. trichoceros (Ehrenb.) Kofoid

C. tripos f. ponticum Jörgensen

Cochlodinium spp.

Dinophysis acuta Ehrenberg

D. acuminata Clap. \& Lach.

D. caudata Saville-Kent

D. dentata Schiller

D. fortii Pavillard

D. hastata Stein

D. sphaerica Stein

D. tripos Gourret

Diplopsalis asymmetrica (Mangin) Lindemann

D. lenticulum (Berg.) Loeblich

Ebria cf. tripartita (Schum.) Lemmermann

Fragilidium subglobosum (v. Stosch) Balech

Gonyaulax digitale (Pouchet) Kofoid

G. kofoidi Pavillard

G. monacantha Pavillard

G. orientalis Linden

G. pacifica Kofoid

G. polyedra Stein

G. polygramma Stein

Gymnodinium agaricoides Campbell

G. breve Davis

G. catenatum Levander

G. coeruleum Dogiel

G. hamulus Kofoid \& Swezy

Gyrodinium aureolum Hulburt

G. estuariale Hulburt

G. fusiforme Kofoid \& Swezy

G. lachryma (Meunier) Kofoid \& Swezy

G. spirale (Bergh.) Kofoid \& Swezy

$H$. triquetra (Ehrenb.) Stein

Katodinium glaucum (Lebour) Loeblich II

Noctiluca miliaris Suriray

Oxyphysis oxytoxoides Kofoid

Oxytoxum adriaticum Schiller 
Table 2 (Continued)

\begin{tabular}{|c|}
\hline $\begin{array}{l}\text { Oxytoxum parvum Schiller } \\
\text { O. scolopax Stein } \\
\text { Peridinium elpatiewskyi (Ostenf.) Schiller } \\
\text { Podolambas bipes Stein } \\
\text { P. elegans Schütt } \\
\text { P. palmipes Stein } \\
\text { P. spinifer Okamura } \\
\text { Polykrikos schwartzii Bütschli } \\
\text { Prorocentrum micans Ehrenberg } \\
\text { P. redfieldi Bursa } \\
\text { P. rostatum Stein } \\
\text { P. scutellum Schröder } \\
\text { P. triestinum Schiller } \\
\text { Protoperidinium breve Paulsen } \\
\text { P. brochi Kofoid \& Swezy } \\
\text { P. cerasus (Paulsen) Balech } \\
\text { P. conicum (Gran) Ostenfeld \& Schmidt } \\
\text { P. depressum (Bailey) Balech } \\
\text { P. diabolus (Cleve) Balech } \\
\text { P. divergens Ehrenberg } \\
\text { P. globulus Stein } \\
\text { P. heteracanthum Dang. } \\
\text { P. leonis Pavillard } \\
\text { P. minusculum Pavillard } \\
\text { P. minutum Kofoid } \\
\text { P. obtusum Karsten } \\
\text { P. pallidum Ostenfeld } \\
\text { P. pedunculatum (Schütt) Balech } \\
\text { P. pentagonum Gran } \\
\text { P. pyriforme Paulsen } \\
\text { P. solidicorne Mangin } \\
\text { P. steinii Jörgensen } \\
\text { P. subinerme Paulsen } \\
\text { Pyrophacus horologicum Stein } \\
\text { Scrippsiella faeroense (Paulsen) Balech \& Soares } \\
\text { Scrippsiella sp. } \\
\text { Cryptophyceae } \\
\text { Chroomonas amphioxeia (Conrad). Butcher } \\
\text { Chroomonas minuta (Skuja) var. apyrenoidosa Hulburt } \\
\text { Cryptomonas pseudobaltica Butcher } \\
\text { Cryptomonas testacea Campbell } \\
\text { Hemiselmis virescens Droop. } \\
\text { Prymnesiophyceae } \\
\text { Chrysochromulina kappa Parke \& Dixon } \\
\text { Chrysochromulina sp. } \\
\text { Hymenomonas carterae Braarud } \\
\text { Parachrysidalis estuariale Hulburt } \\
\text { Prymnesium parvum Carter } \\
\text { Syracosphaera pulchra Lohmann } \\
\text { Prasinophyceae } \\
\text { Pyramimonas amylifera Conrad } \\
\text { P. grossii Parke } \\
\text { P. micron Conrad \& Kufferath } \\
\text { Tetraselmis maculata Butcher } \\
\text { Pold }\end{array}$ \\
\hline
\end{tabular}


siosira eccentrica, T. minima, Thalassiosira sp. 1, Thalassiosira sp. 2), Dinophyceae (Cachonina niei, Gymnodinium agaricoides, G. breve, G. catenatum, Heterocapsa triquetra, Polycricos schwartzii, Prorocentrum micans, P. redfieldii, Scrippsiella sp. 1, Scrippsiella sp. 2), Cryptophyceae (Chroomonas minuta, Cryptomonas pseudobaltica, C. testaceae), Prymnesiophyceae (Chrysochromulina kappa, Hymenomonas carterae, Parachrysidalis estuariale, Syracosphaera pulchra) and Euglenophyceae (Eutreptia lanowii).

Of the above listed species, the pennate diatoms Nitzschia "seriata", N. closterium and the cryptophyte Chroomonas minuta have been observed throughout the year to display one or more peaks of abundance; their contribution to the formation of a phytoplankton assemblage has not, however, been decisive. The rest of the species which are more in number occur at definite periods of short duration (up to three months) with only one peak of abundance. These species along with $N$. seriata, N. closterium and $C$. minuta make up those phytoplankton assemblages which characterize the phytoplankton community of the inner part of Thermaikos Gulf. An outstanding feature of these assemblages is the simultaneous dominance of more than one species.

Five different phytoplankton assemblages, occurring during the year with some overlapping, have been distinguished in the phytoplankton community of the area. The first assemblage, comprising the species $L$. minimus, $N$. closterium, $N$. "seriata", $T$. nitzschioides, T. minima, Thalassiosira sp. 1, C. niei, P. micans, P. redfieldii, Scrippsiella sp., C. minuta, E. lanowii and S. pulchra, was detected in May-July. The second assemblage which occurs from August to October consists of the algae $C$. socialis, $R$. delicatula, S. costatum, T. eccentrica, G. breve, G. catenatum, H. triquetra, Scrippsiella sp. 2., $C$. minuta and $H$. carterae. The third assemblage appears in October to December and is made up of the algae $L$. danicus, $N$. "seriata", S. schroederi, G. breve, $C$. pseudobaltica, $C$. testacea and C. minuta. In January to February we have the fourth assemblage which consists of the algae $N$. "seriata", $R$. fragilissima, G. agaricoides and various $\mu$-flagellates. Finally, the last assemblage was observed in the months of March-April and includes the algae $C$. bergonii, C. granii, $R$. setigera, Thalassiosira sp. 2., P. schwartzii, C. kappa and P. estuariale.

Based on the species that were most important in biomass and abundance, the following annual composition of the phytoplankton community was concluded:

May $26 \mathrm{th}$

Diatoms: L. minimus (1839 cells/ml), Thalassiosira sp. 1. (898 cells/ml), N. "seriata" (395 cells $/ \mathrm{ml}$ ), $N$. closterium (304 cells $/ \mathrm{ml}), T$. nitzschioides (230 cells/ml), Chaetoceros decipiens ( 24 cells $/ \mathrm{ml})$.

Dinoflagellates: Scrippsiella sp. 1. (193 cells/ml), Oxytonum parvum (115 cells $/ \mathrm{ml}), P$. micans $(56$ cells $/ \mathrm{ml}), P$. redfieldii $(24$ cells $/ \mathrm{ml})$.

Other species: Pyramimonas amylifera ( 84 cells/ml), C. minuta ( 83 cells $/ \mathrm{ml}$ ) and unidentified $\mu$-flagellates $(12360$ cells $/ \mathrm{ml})$.

June 24 th

Diatoms: L. minimus (578 cells $/ \mathrm{ml}), T$. minima ( $275 \mathrm{cells} / \mathrm{ml}), N$. closterium ( $41 \mathrm{cells} / \mathrm{ml})$, Bellerochea jucatanensis ( 23 cells $/ \mathrm{ml}$ ).

Dinoflagellates: C. niei $(717$ cells $/ \mathrm{ml}), P$. redfieldii $(139 \mathrm{cells} / \mathrm{ml}), P$. micans $(37 \mathrm{cells} / \mathrm{ml})$.

Other species: C. minuta (2077 cells/ml), E. lanowii (84 cells/ml), S. pulchra (440 cells/ml) and unidentified $\mu$-flagellates (1203 cells $/ \mathrm{ml}$ ). 
July $22 \mathrm{nd}$

Diatoms: Thalassiosira rotula ( $44 \mathrm{cells} / \mathrm{ml}), T$. minima $(22 \mathrm{cells} / \mathrm{ml}), T$. nitzschioides $(19$ cells $/ \mathrm{ml}), N$. "seriata" (14 cells $/ \mathrm{ml}), N$. closterium ( 9 cells $/ \mathrm{ml})$.

Dinoflagellates: $P$. redfieldii ( 156 cells $/ \mathrm{ml})$, Gymnodinium spp. ( 45 cells $/ \mathrm{ml}$ ), P. micans (16 cells/ml).

Other species: C. minuta (524 cells/ml), Cryptomonas sp. (212 cells/ml), S. pulchra (126 cells $/ \mathrm{ml})$ and Eutreptia lanowii (19 cells $/ \mathrm{ml})$.

August 20 th

Diatoms: S. costatum ( 232 cells $/ \mathrm{ml})$, Chaetoceros $\mathrm{sp}$. (185 cells $/ \mathrm{ml}), R$. delicatula ( 49 cells/ $\mathrm{ml}), N$. closterium ( $25 \mathrm{cells} / \mathrm{ml})$, Bellerochea jucatanensis $(12 \mathrm{cells} / \mathrm{ml})$.

Dinoflagellates: Scrippsiella sp. 2. (65 cells/ml), P. redfieldii (48 cells $/ \mathrm{ml}), H$. triquetra $(25$ cells $/ \mathrm{ml})$, G. catenatum ( 25 cells $/ \mathrm{ml}$ ), Pyrophacus horologicum ( 4 cells $/ \mathrm{ml}$ ).

Other species: $H$. carterae $(45 \mathrm{cells} / \mathrm{ml}), C$. minuta $(125 \mathrm{cells} / \mathrm{ml})$ and unidentified $\mu$ flagellates ( 1250 cells $/ \mathrm{ml})$.

Sep tem ber $27 \mathrm{th}$

Diatoms: S. costatum (348 cells $/ \mathrm{ml}), C$. socialis $(150$ cells $/ \mathrm{ml}), T$. eccentrica $(99 \mathrm{cells} / \mathrm{ml})$, $N$. closterium (100 cells $/ \mathrm{ml}), R$. delicatula $(49$ cells $/ \mathrm{ml})$.

Dinoflagellates: $H$. triquetra ( 125 cells/ml), Scrippsiella sp. $2(65 \mathrm{cells} / \mathrm{ml})$.

Other species: Cryptomonas spp. (78 cells $/ \mathrm{ml})$, Hemiselmis virescens $(94 \mathrm{cells} / \mathrm{ml})$, Pyramimonas spp. ( $45 \mathrm{cells} / \mathrm{ml}$ ) and unidentified $\mu$-flagellates $(450 \mathrm{cells} / \mathrm{ml})$.

October $30 \mathrm{th}$

Diatoms: $T$. eccentrica $(56$ cells $/ \mathrm{ml}), N$. closterium $(45$ cells $/ \mathrm{ml}), L$ danicus $(21$ cells $/ \mathrm{ml})$, N. "seriata" (14 cells $/ \mathrm{ml})$.

Dinoflagellates: G. breve $(77$ cells $/ \mathrm{ml}), P$. diabolus $(7$ cells $/ \mathrm{ml})$.

Other species: $C$. testacea $(550 \mathrm{cells} / \mathrm{ml}), C$. minuta $(130 \mathrm{cell} / \mathrm{ml})$, Pyramimonas spp. (56 cells $/ \mathrm{ml}$ ) and unidentified $\mu$-flagellates ( 910 cells $/ \mathrm{ml})$.

November $19 \mathrm{th}$

Diatoms: $N$. "seriata" (159 cells/ml), S. schroederi (185 cells $/ \mathrm{ml})$, Chaetoceros spp. (45 cells $/ \mathrm{ml}), L$. danicus ( 25 cells $/ \mathrm{ml})$.

Dinoflagellates: Gymnodinium spp. (36 cells/ml), G. breve (14 cells $/ \mathrm{ml})$, Gonyaulax spp. (18 cells/ml).

Other species: C. pseudobaltica (1899 cells $/ \mathrm{ml})$, C. testacea (143 cells $/ \mathrm{ml})$, Pyramimonas spp. ( 46 cells/ml), Ebria cf. tripartita ( 15 cells $/ \mathrm{ml}$ ) and unidentified $\mu$-flagellates (623 cells $/ \mathrm{ml})$.

December 22 th

Diatoms: L. danicus ( 37 cells/ml), Chaetoceros danicus ( 36 cells/ml), Ditylum brightwellii (8 cells $/ \mathrm{ml})$.

Dinoflagellates: Gonayaulax spp. (41 cells $/ \mathrm{ml}$ ).

Other species: C. minuta (659 cells/ml), C. testaceae (14 cells $/ \mathrm{ml})$, Pyramimonas micron $(28 \mathrm{cells} / \mathrm{ml})$ and unidentified $\mu$-flagellates $(394 \mathrm{cells} / \mathrm{ml})$.

$\mathrm{J}$ anuary $24 \mathrm{th}$

Diatoms: N. "seriata" (214 cells $/ \mathrm{ml})$, R. fragilissima ( 50 cells $/ \mathrm{ml}), R$. setigera ( 16 cells $/ \mathrm{ml})$, D. brightwellii (12 cells $/ \mathrm{ml})$. 
Dinoflagellates: Katodinium glaucum (72 cells/ml), Scrippsiella spp. (42 cells/ml), Diplopsalis lenticula ( 8 cells/ml).

Other species: C. minuta $(249$ cells $/ \mathrm{ml})$, Cryptomonas spp. (50 cells $/ \mathrm{ml})$, Pyramimonas grossii $(133 \mathrm{cells} / \mathrm{ml})$ and unidentified $\mu$-flagellates $(890 \mathrm{cells} / \mathrm{ml})$.

February 20 th

Diatoms: N. “seriata” (285 cells/ml), R. fragilissima (182 cells $/ \mathrm{ml})$, R. setigera (12 cells/ $\mathrm{ml})$.

Dinoflagellates: $G$. agaricoides (1604 cells $/ \mathrm{ml})$.

Other species: Cryptomonas spp. (598 cells $/ \mathrm{ml}$ ), C. minuta (116 cells $/ \mathrm{ml})$, Prymnesium parvum (112 cells $/ \mathrm{ml}$ ) and unidentified $\mu$-flagellates $(4080 \mathrm{cells} / \mathrm{ml})$.

March 16 th

Diatoms: $N$. "seriata" (247 cells/ml), $R$. setigera ( 242 cells $/ \mathrm{ml})$.

Dinoflagellates: Gonyaulax spp. (38 cells/ml), G. agaricoides $(20$ cells $/ \mathrm{ml})$, P. schwartzii (11 cells/ml), Gyrodinium lachryma (8 cells $/ \mathrm{ml})$.

Other species: $P$. parvum (39 cells $/ \mathrm{ml})$ and unidentified $\mu$-flagellates $(1060$ cells $/ \mathrm{ml})$.

April 20 th

Diatoms: Thalassiosira sp. 2 (1715 cells/ml), C. granii ( 34 cells/ml), C. bergonii (30 cells/ $\mathrm{ml})$.

Dinoflagellates: G. agaricoides ( 30 cells $/ \mathrm{ml})$, P. redfieldii $(25$ cells $/ \mathrm{ml})$, Diplopsalis sp. (13 cells $/ \mathrm{ml}), P$. scutellum ( 5 cells $/ \mathrm{ml}), P$. schwartzii $(3$ cells $/ \mathrm{ml})$.

Other species: $P$. estuariale $(2450$ cells $/ \mathrm{ml})$, Tetraselmis gracilis $(489$ cells $/ \mathrm{ml})$, Cryptomonas spp. (214 cells/ml), C. kappa (642 cells/ml), E. lanowii $(30 \mathrm{cells} / \mathrm{ml})$.

\section{Annual cycle of phytoplankton biomass}

There were three maxima of phytoplankton biomass observed through the year (Fig. 2). The first peak $\left(6700 \mathrm{mg} / \mathrm{m}^{3}\right)$, at the end of spring, is composed of diatoms $(68.5 \%)$

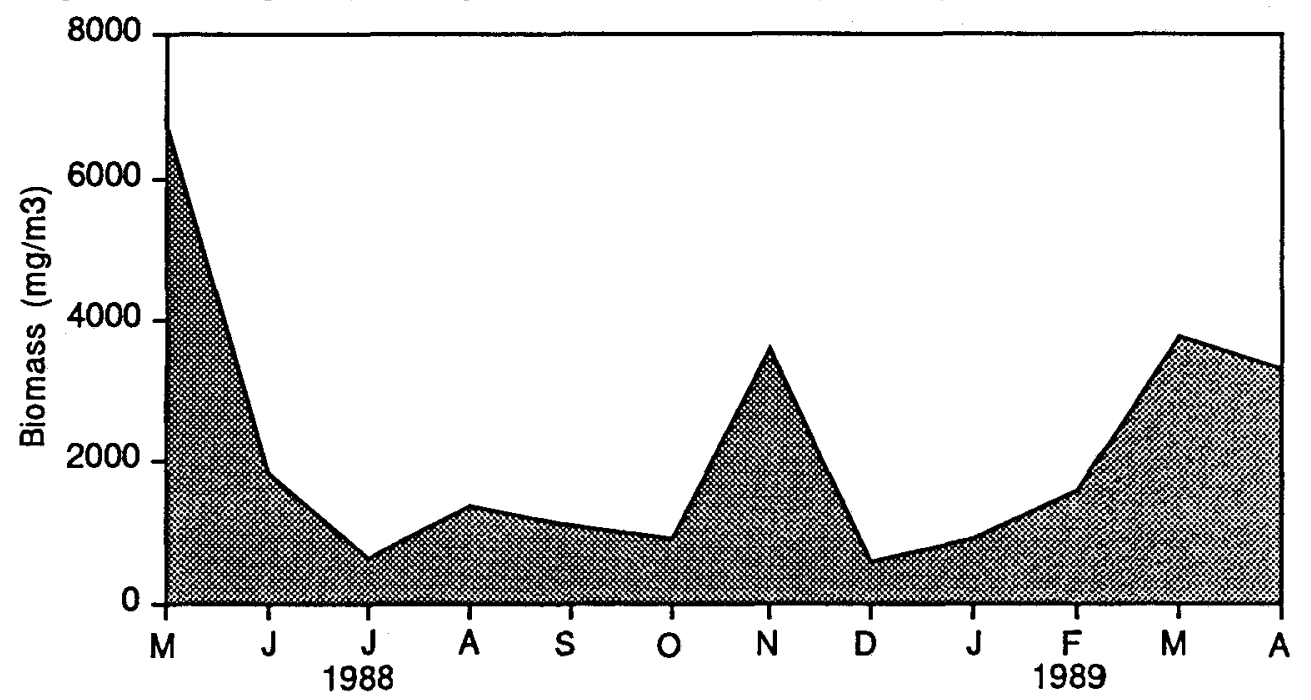

Fig. 2. Seasonal variations of phytoplankton biomass 
and dinoflagellates (24.6\%) (Fig. 3). The autumn peak $\left(3597 \mathrm{mg} / \mathrm{m}^{3}\right)$ is formed of diatoms $(73.4 \%)$ and cryptophytes $(20.7 \%)$, while the third peak $\left(3700 \mathrm{mg} / \mathrm{m}^{3}\right)$ occurring in early spring is constituted of dinoflagellates $(55.7 \%)$ and diatoms $(43.1 \%)$.

The monthly changes in the biomass of different phytoplankton groups are given in Figure 4 . The annual cycle of the diatom biomass presents three maxima. At the first peak $\left(4595 \mathrm{mg} / \mathrm{m}^{3}\right.$ ) in May 1988, the centric diatom Thalassiosira sp. with $878 \mathrm{cell} / \mathrm{s} / \mathrm{ml}$ contributes $75 \%$ of the biomass. The second biomass peak $\left(2641 \mathrm{mg} / \mathrm{m}^{3}\right)$ observed at the end of autumn is mainly composed of the centric diatom Schroederella schroederi $(89.6 \%)$. The third peak $\left(2150 \mathrm{mg} / \mathrm{m}^{3}\right)$ in April 1989 is composed of Thalassiosira sp. $(52 \%)$ and Coscinodiscus granii $(31.5 \%)$. The contribution of the diatom biomass to the total phytoplankton biomass ranged from 9 to $73 \%$.

The monthly variations in the biomass of dinoflagellates presented two maxima. At the first peak $\left(1653 \mathrm{mg} / \mathrm{m}^{3}\right)$ in May 1988, the species Prorocentrum micans and Scrippsiella sp. dominated contributing $75 \%$ to the phytoplankton biomass. At the second peak (2107 $\mathrm{mg} / \mathrm{m}^{3}$ ) in March 1989, the phagotrophic Polykrikos schwarzii made up the greatest part $(75 \%)$ of the biomass.

Cryptophytes occurred with only one main maximum $\left(746 \mathrm{mg} / \mathrm{m}^{3}\right)$ at the end of

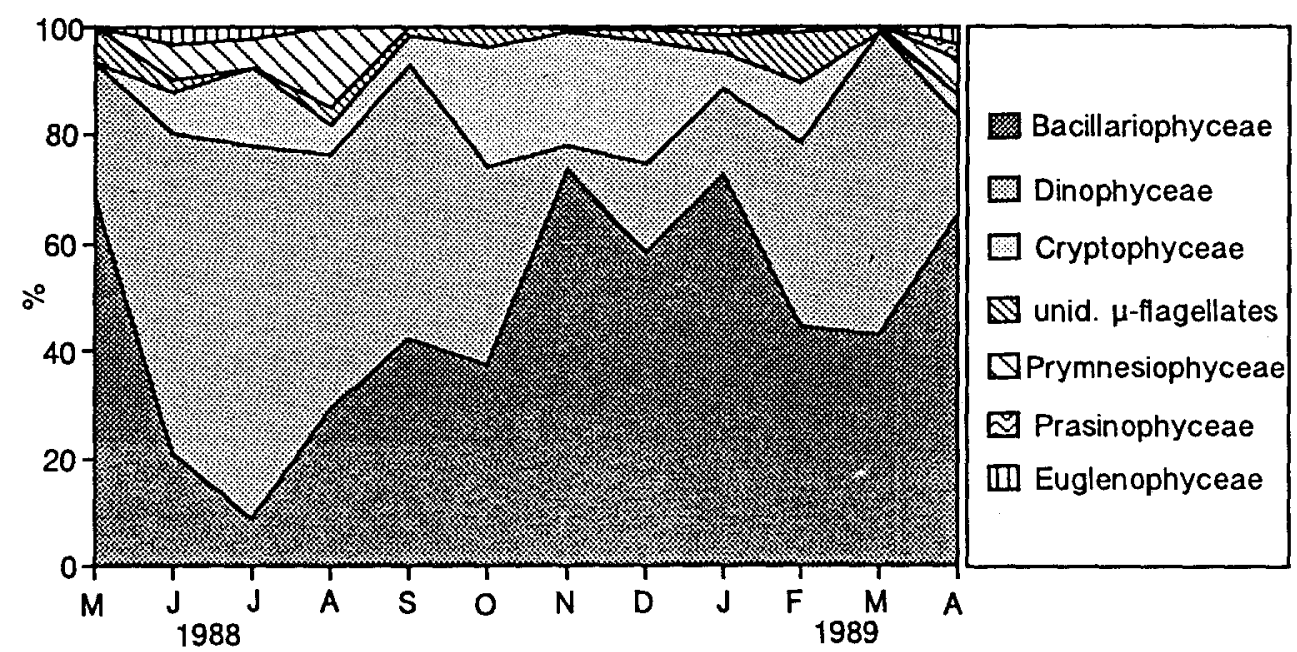

Fig. 3. Percentage contribution of the different algal groups to the total phytoplankton biomass. unid. = unidentified

autumn. The species Cryptomonas of. pseudobaltica largely contributes (88\%) to this maximum. The monthly variations in the biomass of the haptophytes had two maxima, one in August $1988\left(202 \mathrm{mg} / \mathrm{m}^{3}\right)$ in which the species Hymenomonas carterae prevailed and the other in April 1989 when the species Parachrysidalis estuariale and Chrysochomulina kappa were dominant. In April 1989, maxima of the prasinophytes (92 $\mathrm{mg} /$ $\left.\mathrm{m}^{3}\right)$ and euglenophytes $\left(112 \mathrm{mg} / \mathrm{m}^{3}\right)$ biomass were observed with Tetraselmis gracilis and Eutreptia lanowii as dominating species, respectively. 

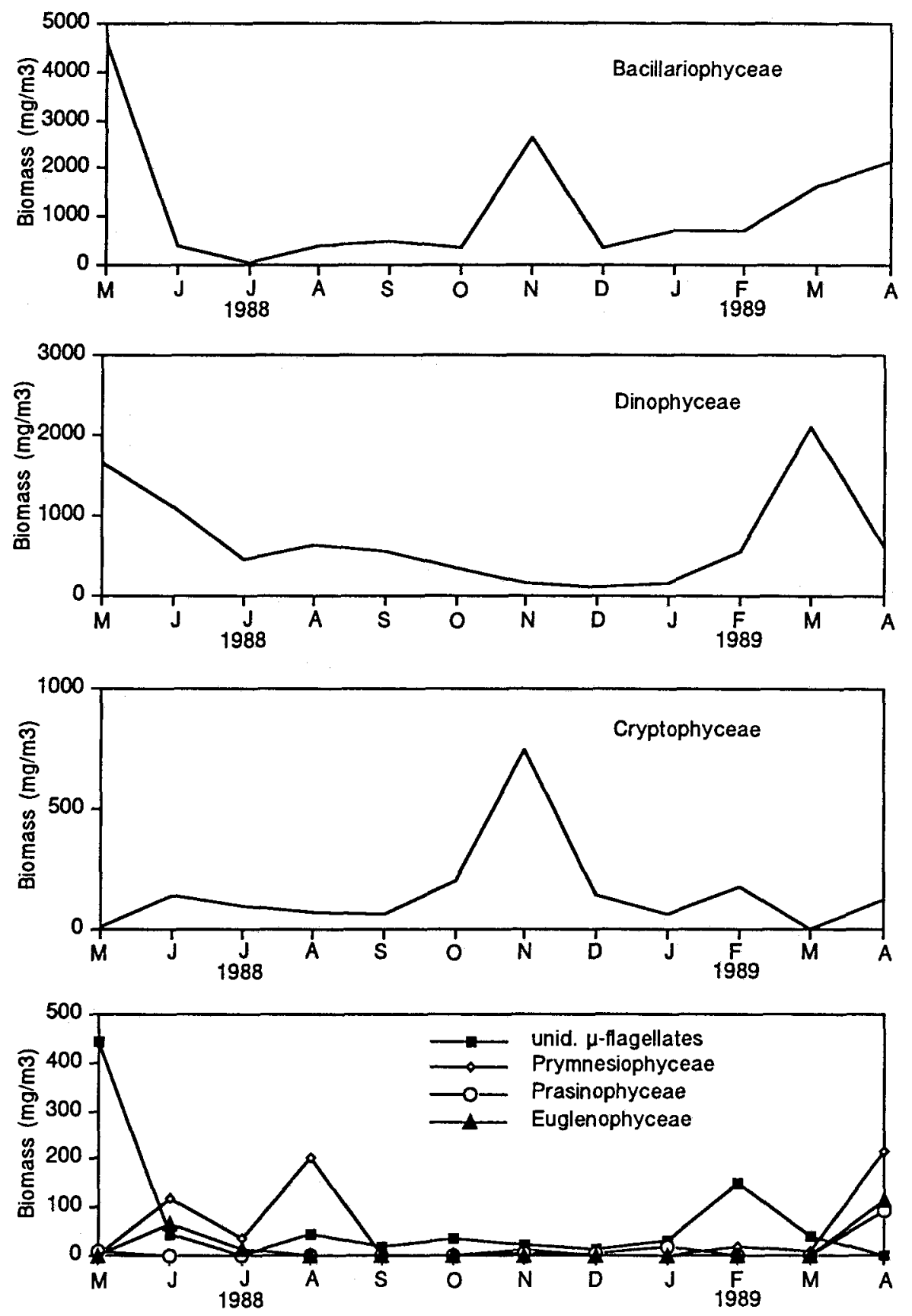

Fig. 4. Monthly fluctuations in the biomass of the different algal groups. unid. $=$ unidentified 


\section{DISCUSSION}

The Gulf of Thermaikos is an ecosystem influenced in many ways by anthropogenic processes. The consequences of these processes are most evident in the inner part of the Gulf which is in the immediate vicinity of the city of Thessaloniki.

The frequent changes in the concentrations of nutrients, which do not follow the simple patterns of non-polluted areas, the high concentrations of inorganic phosphorus and the low values of the N:P ratio (Samanidou et al., 1987; Nikolaides \& MoustakaGouni, in prep.) in relation to the large fluctuations in salinity, differentiate the area from other gulfs and stress the anthropogenic influence.

In a marine ecosystem which is continually affected exogenously, one finds it difficult to determine the particular environmental conditions favouring the phytoplankton growth and to predict the consequences. This becomes a major problem, especially in cases such as that observed in Thermaikos Gulf, where there is very little information available on the phytoplankton.

The phytoplankton composition of the inner part of the Gulf is generally similar to other areas of the Mediterranean: Saronikos Gulf (Ignatiades 1976, 1984), the Adriatic coasts (Pucher-Petkovic, 1966), (Solazzi \& Andreoli, 1971), the Ligurian Sea (Bernhard \& Rampi, 1967), the Gulf of Naples (Scotto et al., 1985), the Gulf of Marseilles (Travers, 1975). Common features are also noticed in the phytoplankton of brackish waters, such as the development of the species Ceratium furca, C. fusus, Gymnodinium agaricoides, Eutreptia lanowii and the striking abundance of phytoflagellates mainly from the classes Cryptophyceae, Haptophyceae and Prasinophyceae which are encountered almost throughout the year.

The phytoplankton biomass seems to be mainly affected by the nutrients $\mathrm{N}$ and $\mathrm{Si}$, and by zooplankton grazing. The low biomass values observed in July $\left(653 \mathrm{mg} / \mathrm{m}^{3}\right)$ and October $\left(904 \mathrm{mg} / \mathrm{m}^{3}\right)$ along with the low concentrations of the total inorganic nitrogen (42 and $44 \mu \mathrm{g} / \mathrm{l}$, respectively) and silicon ( 22 and $31 \mu \mathrm{g} \mathrm{SiO}{ }^{2}-\mathrm{Si} / \mathrm{l}$ ) may indicate a limitation of phytoplankton caused by lack of nutrients (N, Si). Phytoplankton limitation caused by lack of phosphorus, on the other hand, does not seem to take place, since phosphorus was in excess all year round. Nitrogen as the limiting nutrient factor in this area has been stressed by Nikolaides \& Moustaka-Gouni (in prep.), a fact which is found to be in accordance with observations by Ryther \& Dustan (1971). The phytoplankton biomass minimum $(614 \mathrm{mg} / \mathrm{m})$ detected in December does not appear to be related to the nutrients, whose concentrations reached their maximum values the same month. This low biomass may have been due to grazing by zooplankton since large population densities of Tintinnidae ( 11 cells/ml) were observed. Control of the phytoplankton biomass by the zooplankton could also occur in January when the relatively minor increase of the phytoplankton biomass cannot be held responsible for a pronounced decrease in nutrients. It appears that the newly produced phytoplankton consumes the available nutrients and is simultaneously consumed by the zooplankton whose population densities are kept high till April.

As regards the grouping of species, which collectively made up the phytoplankton assemblages, and the succession tendencies encountered in the inner part of Thermaikos Gulf, it is difficult, with the information we have in our possession, to isolate any specific factor which might regulate these processes. In fact, single-factor regulation of a given 
species' succession seems unlikely. Multiple and changing combinations of factors, together with their interactions, probably regulate succession (Smayda, 1980).

The simultaneous dominance of more than one species as in the case of the phytoplankton community of Thermaikos Gulf is probably due to the frequent changes of environmental conditions, a fact which offers the possibility of its exploitation in more phytoplanktonic organisms during a definite period of time.

The phytoplankton assemblages in the inner part of the Gulf appear to bear similarities to the succession stages sensu Margalef (1958). In August to October the small-celled diatoms Skeletonema costatum, Chaetoceros socialis are the species predominating in the phytoplankton, species which characterize stage I (Margalef). Stage I is, however, typical of turbulent and nutrient-enriched waters whereas in Thermaikos Gulf the water mass is stratified at this period. Mixing in the water column begins in October, and the October-December assemblage could be regarded as the starting point of the phytoplankton succession in the research area. This assemblage, however, differs from Stage I of Margalef and is characterized by large diatoms (Schroederella schroederi). Is there a reserve trend in Thermaikos Gulf from that proposed by Margalef, in other words, does succession proceed from large to smaller cells?

Continuation of this research and selection of more information will hopefully shed more light on all those questions relevant to the ecology of the phytoplankton in Thermaikos Gulf.

Acknowledgements. The first author would like to thank Dr. Drebes and Dr. Elbrächter (Wattenmeerstation, Sylt, Federal Republic of Germany) for their assistance in species identification. We are also grateful to $M$. Seferli for supporting the research in the lab. Thanks are due to A. KiratzidouDimopoulou for assisting in the preparation of the text in the English language. This research was partially supported by the Ministry of Environment, Physical Planning, Public Works and Agriculture.

\section{LITERATURE CITED}

Anagnostidis, K., 1968. Untersuchıngen über die Salz- und Süßwasser-Thiobiocönosen (Sulphuretum) Griechenlands. - Wiss Jb. phys.-math. Fak. Univ. Thessaloniki 10, 406-46.

Athanasopoulos, G., 1931a. Dinoflagellés du golfe de Salonique. - Bull. Inst. océanogr. 576, 1-4.

Athanasopoulos, G., 1931b. Microfaune du golfe de Salonique, etc. - Bull. Inst. océanogr. 588, 1-26.

Bernard, M. \& Rampi, L., 1967. The annual cycle of the "Utermöhl-phytoplankton" in the Ligurian Sea in 1959 and 1962. - Pubbl. Staz. zool. Napoli 35, 137-169.

Campbell, H. P., 1973. The phytoplankton of Gales Creek with emphasis on the taxonomy and ecology of estuarine phytoflagellates. Ph.D. Thesis, Univ. of North Carolina, 398 pp.

Cupp, E. E., 1943. Marine plankton diatoms of the west coast of North America. - Bull. Scripps Inst. Oceanogr. (Tech. Ser.) 5, 1-238.

Drebes, G., 1974. Marines phytoplankton. Thieme, Stuttgart, 186 pp.

Edler, L., 1979. Recommendations for marine biological studies in the Baltic Sea. Phytoplankton and chlorophyll. - Balt. mar. Biol. 5, 5-38.

Friligos, N. \& Koussouris, T., 1984. Preliminary observations on sewage nutrient enrichment and phytoplankton ecology in the Thermaikos Gulf, Thessaloniki, Greece. - Vie Milieu 34, 35-39.

Haritonidis, S., 1978. Contribution to the research of marine plant macrophyceae (Chloro-, Phaeoand Rhodophyceae) of Thermaikos Gulf. Diss., Univ. Thessaloniki, 175 pp. (In Greek with English summary).

Hustedt, F., 1930. Die Kieselalgen Deutschlands, Österreichs und der Schweiz mit Berücksichtigung der übrigen Länder Europas sowie der angrenzenden Meeresgebiete. Akad. Verl.Ges., Leipzig, 920 pp. 
Ignatiades, L., 1976. The standing stock of diatoms and dinoflagellates in the oligotrophic waters of southern Aegean Sea. - Int. Revue ges. Hydrobiol. 61, 193-199.

Ignatiades, L., 1984. Coarse-scale horizontal distribution of phytoplankton in a semi-enclosed Coastal area. - Mar. Ecol. 5, 217-227.

Koukouras, A., 1979. Bionomic study of the macrofauna of the mediolittoral soft substratum in Strymonikos and Thermaikos Gulfs. Diss., Univ. Thessaloniki, 283 pp. (In Greek with English summary).

Liddicoat, M. I., Tibbits, S. \& Butler, M. I., 1976. The determination of ammonia in natural waters. Wat. Res. 10, 567-568.

Margalef, R., 1958. Temporal succession and spatial heterogeneity in phytoplankton. In: Perspectives in marine biology. Ed. by A. A. Buzzati-Traverso. Univ. of California Press, Berkeley, 323-349.

Nikolaidis, G., 1985. Qualitative and quantitative investigation of the marine plant macrophyceae (Chloro-, Phaeo- and Rhodophyceae) in different polluted areas (Thessaloniki Gulf) and not polluted areas (Chalkidiki). Diss., Univ. Thessaloniki, 156 pp. (In Greek with English summary).

Pucher-Petkovic, T., 1966. Végétation des diatomées pélagiques de l'Adriatique moyenne. - Acta adriat. 13, 1-97.

Rampi, L. \& Bernhard, M., 1980. Chiave per la determinazione delle peridinee pelagiche mediterranee. - Comitato Nazionale Energia Nucleare (CNEN), RT/BIO 8, 1-193.

Ryther, J. H. \& Dunstan, W. M., 1971. Nitrogen, phosphorus and eutrophication in the coastal marine environment. - Science, N. Y. 171, 1008-1013.

Samanidou, V., Fytianos, K. \& Vasilikiotis, G., 1987. Distribution of nutrients in the Thermaikos Gulf, Greece. - Sci. total Environ. 65, 181-89.

Schiller, J., 1933. Dinoflagellatae. In: Rabenhorst's Kryptogamen-Flora von Deutschland, Österreich und der Schweiz. Akad. Verl.Ges., Leipzig (Reprint: Johnson, New York) 10 (1), 1-617.

Schiller, J., 1937. Dinoflagellatae. In: Rabenhorst's Kryptogamen - Flora von Deutschland, Österreich und der Schweiz. Akad. Verl.Ges., Leipzig. (Reprint: Johnson, New York) 10 (2), 1-589.

Scotto di Carlo, B., Tomas, C. R., Ianora, A., Marino, D., Mazzochi, M. G., Modigh, M., Montresor, M., Petrillo, L., Ribera d'Alcala, M., Saggiomo, V. \& Zingone, A., 1985. Uno studio integrato dell'ecosistema pelagico costiero del golfo di Napoli. - Nova Thalassia 7, 99-128.

Smayda, T., 1980. Phytoplankton species succession. In: The physiological ecology of phytoplankton. Ed. by I. Morris. Univ. of California Press, Berkeley, 493-570.

Solazzi, A. \& Andreoli, C., 1971. Produttività e ciclo annuale del fitoplancton nel medio Adriatico occidentale, - Quad. Lab. Tecnol. Pesca, Ancona 1 (1), Suppl. 1-90.

Strickland, J. D. H. \& Parsons, T. R., 1968. A practical handbook of seawater analysis. - Bull. Fish. Res. Bd Can. 167, 1-311.

Travers, M., 1975. Inventaire des protistes du golfe de Marseille et de ses parages. - Annls Inst. Oceanogr., Monaco, 51, 51-75.

Utermöhl, H., 1958. Zur Vervollkommnung der quantitativen Phytoplankton-Methodik. - Mitt. int. Verein. theor. angew. Limnol. 9, 1-38.

Zarkanellas, A., 1980. Ecological study of macrobenthos in the Thermaikos Gulf. Diss., Univ. Thessaloniki, 147 pp. (In Greek with English summary). 